\title{
The effects of sleeve gastrectomy on shoe size one year after surgery
}

\author{
Ozan Şen, Ahmet Gökhan Türkçapar, Mehmet Ali Yerdel
}

\begin{tabular}{|c|c|}
\hline \multirow[t]{5}{*}{ ABSTRACT } & $\begin{array}{l}\text { Objective: The aim of this study is to evaluate the effects of sleeve gastrectomy on shoe size one year after the pro- } \\
\text { cedure. To our knowledge, no study has yet been conducted addressing this issue. }\end{array}$ \\
\hline & $\begin{array}{l}\text { Material and Methods: Patients who were prepared for sleeve gastrectomy were eligible for the study, and all } \\
\text { data and preoperative shoe sizes were recorded in our prospective database. At the } 12^{\text {th }} \text { month of follow-up, each } \\
\text { patient's excess weight loss } \% \text { was calculated, and their shoe sizes were recorded by verbal report. Arbitrary or half- } \\
\text { size changes were not taken into consideration. The probability of a change in shoe size and the effects of age, sex, } \\
\text { preoperative body mass index, and } 12 \text { th month excess weight loss } \% \text { on this change were investigated. } p<0.05 \text { was } \\
\text { regarded as statistically significant. }\end{array}$ \\
\hline & $\begin{array}{l}\text { Results: The subjects of the study were } 212 \text { patients who completed their } 12 \text {-month follow-ups after sleeve gastrec- } \\
\text { tomy between January } 2012 \text { and February } 2016 \text {. The mean shoe size was } 41.5 \text {; this decreased to } 40.5 \text { one year after } \\
\text { sleeve gastrectomy }(p<0.001) \text {. In patients with body mass index }(\mathrm{BMI})>50 \text {, both the mean decrease }(p=0.008) \text { and } \\
\text { the percentage of at least two size decreases }(p=0.009) \text { were significantly higher than those in patients with } B M I<40 \text {. } \\
\text { Age, sex, and excess weight loss \% did not have any significant effects on shoe size. }\end{array}$ \\
\hline & $\begin{array}{l}\text { Conclusion: Sleeve gastrectomy was clearly associated with decrease in shoe size after } 12 \text { months. Only preoperative } \\
\text { body mass index was found to be directly associated with this decrease. }\end{array}$ \\
\hline & Keywords: Bariatric surgery, sleeve gastrectomy, shoe size \\
\hline
\end{tabular}

Cite this paper as: Şen 0, Türkçapar AG, Yerdel MA. The effects of sleeve gastrectomy on shoe size one year after surgery. Turk J Surg 2017; 33: 284-287.

Department of General Surgery, Bariatrics Surgery, İstanbul Bariatrics, İ stanbul, Turkey

This study was presented at the Bariatric and Metabolic Surgery Congress, 19-22 November 2015, Antalya, Turkey.

\section{Address for Correspondence} Ozan Şen

e-mail:0zansen77@hotmail.com

Received: 27.04.2016

Accepted: 18.11.2016

(C) Copyright 2017

by Turkish Surgical Association

\section{INTRODUCTION}

New evidence strongly suggests that bariatric surgery extends the lifespan of morbidly obese patients; therefore, the number of bariatric operations performed worldwide is increasing (1-7). The introduction of sleeve gastrectomy (SG) to the armamentarium of bariatric surgeons during the last decade probably effected this exponential increase due to its technical ease, physiological nature, and comparable mid-term results (8-10). SG is arguably becoming the new gold standard bariatric procedure, and the demand for this procedure is continually increasing $(9,7)$. Depending on the definition of "ideal body weight" and the timing of preoperative weight measurement, the expected excess weight loss (EWL) \% one year after SG is reported to be between 60 and $100(8,11,12)$. This considerable reduction in body weight, in addition to increasing life quality and expectancy, is expected to necessitate the purchase of a new wardrobe, as is known by the entire bariatric community. Observational experience also suggests that a decrease in shoe size can occur following a bariatric procedure, although this has never been scientifically investigated.

The main aim of this study is to prospectively evaluate changes in shoe size one year following SG. To our knowledge, our study represents the first report that addresses this issue.

\section{MATERIAL AND METHODS}

All patients prepared for SG were eligible for the study. The demographics, preoperative and operative data, postoperative complications, and follow-up results of the patients were recorded in our prospective database. Preoperative shoe size and body mass index $\left(\mathrm{BMI}, \mathrm{kg} / \mathrm{m}^{2}\right)$ were recorded once the surgery was scheduled. European shoe sizing wasused.

All operations were performed by the same team using a standard technique. Briefly, special care was taken to excise the antrum, starting 2 to 3 centimeters from the pylorus; wide excision of the fundus was also enforced. Our procedure also involved purse string inversion of the upper corner and full thickness, as well as continuous suturing of the entire staple line after the $36 \mathrm{~F}$ bougie was withdrawn. All patients were seen at the clinic three months and one year after surgery and then at yearly intervals. The $12^{\text {th }}$ month postoperative follow-up visit was the endpoint for this study; the patient's shoe size and weight in kilograms were recorded again, and the EWL \% was calculated. The change in shoe size was estab- 
Table 1. Preoperative versus 12-month postoperative shoe sizes

\begin{tabular}{|c|c|c|c|}
\hline & $\begin{array}{l}\text { Preoperative shoe size } \\
\text { (mean, median, SD) }\end{array}$ & $\begin{array}{l}\text { 12-month postoperative shoe size } \\
\text { (mean, median, SD) }\end{array}$ & $\begin{array}{l}\text { Preoperative versus } 12 \text {-month } \\
\text { postoperative shoe size }\end{array}$ \\
\hline All patients (n: 212 ) & $(41.5,41,2.7)$ & $(40.5,40,2.7)$ & $p<0.001$ \\
\hline Male (n: 85) & $(44.2,44,1.8)$ & $(43.2,43,1.75)$ & $p<0.001$ \\
\hline Female (n: 127) & $(39.7,40,1.5)$ & $(38.6,39,1.4)$ & $p<0.001$ \\
\hline Age 40 years< $(n: 84)$ & $(41.4,41,2.8)$ & $(40.5,40,2.8)$ & $p<0.001$ \\
\hline Age 40 years> (n: 128) & $(41.5,41,2.58)$ & $(40.5,40,2.6)$ & $p<0.001$ \\
\hline BMI<40 (n: 55) & $(40.3,40,2.3)$ & $(39.5,39,2.4)$ & $p<0.001$ \\
\hline $40<\mathrm{BMI}<50$ (n: 105) & $(41.6,41,2.7)$ & $(40.6,40,2.8)$ & $p<0.001$ \\
\hline $\mathrm{BMI}>50$ (n: 52) & $(42.6,42.5,2.8)$ & $(41.3,42,2.7)$ & $\mathrm{p}<0.001$ \\
\hline EWL \%<75 (n: 70) & $(42.04,42,2.5)$ & $(40.97,40.5,2.5)$ & $p<0.001$ \\
\hline 75<EWL \%<100 (n: 84) & $(41.9,41,2.8)$ & $(40.9,40,2.8)$ & $p<0.001$ \\
\hline EWL \%>100 (n: 58) & $(40.2,40,2.4)$ & $(39.3,39,2.6)$ & $\mathrm{p}<0.001$ \\
\hline
\end{tabular}

BMI: body mass index; EWL: excess weight loss; SD: standard deviation

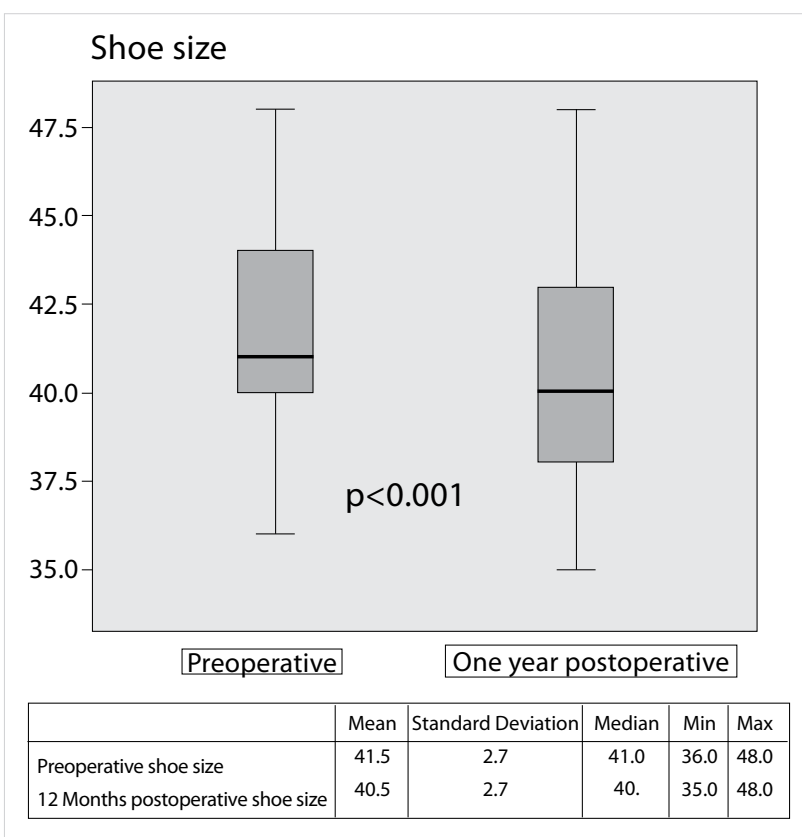

Figure 1. Preoperative and 12-month postoperative shoe sizes

lished by a direct verbal report obtained from each patient. Half-size or similar arbitrary reductions that did not result in at least one shoe size change were not taken into consideration (i.e., any patient declaring a half-size reduction was recorded as "no change," a size reduction of 1.5 was recorded as a size change of 1 , and a size reduction of 2.5 was recorded as a size change of 2). The EWL \% was calculated by accepting the ideal body weight as equivalent to a BMI of $25 \mathrm{Kg} / \mathrm{m}^{2}$.

The effect of age on the probability of shoe size change was calculated by comparing the shoe size decreases in patients older and younger than 40 years of age. The effect of preoperative BMI on shoe size change was evaluated by comparing the decreases in three consecutive preoperative BMl groups, which were defined as $<40,40$ to 50 , and $>50 \mathrm{Kg} / \mathrm{m}^{2}$. The probable association between shoe size change and EWL \% was assessed by comparing the reduction figures in three consecutive groups of EWL \%, defined as $<75,75$ to 100 , and $>100$.

This study was conducted in accordance with the ethical standards set out in the Helsinki Declaration.

\section{Statistical Analysis}

All statistical analysis was performed using the Statistical Package for the Social Sciences software for MacOS X 21 (SPSS Inc.; Chicago, IL, USA). The normal distribution of numeric values was checked with the Kolmogorov-Smirnov test. Numeric variables, such as the difference in shoe size one year after SG, were evaluated by the Wilcoxon test. Decreases in the consecutive BMI and EWL \% groups were evaluated by the Kruskal-Wallis test. Shoe size change categories in the consecutive BMI groups and the effects of age and sex on shoe size decrease were evaluated by $x 2$ tests. $p$ values (type one error) smaller than 0.05 were accepted as significant.

\section{RESULTS}

Between January 2012 and February 2016, among 382 patients who underwent SGs at our institution, 212 completed their 12th month follow-up; these patients are the subject of the present study. No mortality, conversion, leaks, or major complications were observed in these 212 patients. The mean preoperative BMI and age were 45 (min: 33, max: 70) and 37 (min: 14, max: 63), respectively. Of the patients, 60\% were female and $40 \%$ were male ( $\mathrm{n}: 127 / 85)$. The mean preoperative shoe size was 41.5 (Figure 1). The mean EWL \% 12 months after surgery was $87 \%$ ( $\min : 30, \max : 172, \pm 24)$. The mean shoe size one year after surgery was 40.5 , and this decrease from 41.5 was found to be highly significant $(p<0.001$, Figure 1, Table 1). The distributions of shoe size change in both sexes are shown in Figure 2. The decreases in shoe size at 12 months following SG were similar in both women and men $(p=0.356)$. Patients older than 40 years of age ( $n$ : 84) had almost the same decrease in shoe size as patients younger than 40 years $(p=0.99)$. Only preoperative BMI was found to be associated with decrease in shoe size. This asso- 
Table 2. Shoe size decrease categories in consecutive body mass index (BMI) groups

\begin{tabular}{|c|c|c|c|c|}
\hline \multirow[t]{2}{*}{$\mathrm{Kg} / \mathrm{m}^{2}$} & \multirow{2}{*}{$\begin{array}{c}\text { SHOE } \\
\text { No change }\end{array}$} & \multicolumn{2}{|c|}{ SIZE } & \multirow[b]{2}{*}{ Total } \\
\hline & & Minimum one size change & Minimum two size changes & \\
\hline $\mathrm{BMI}<40$ & $\begin{array}{c}n: 16 \\
(29.1 \%)\end{array}$ & $\begin{array}{c}n: 33 \\
(60.0 \%)\end{array}$ & $\begin{array}{c}n: 6 \\
(10.9 \%)\end{array}$ & 55 \\
\hline $40<\mathrm{BMI}<50$ & $\begin{array}{c}\mathrm{n}: 24 \\
(22.8 \%)\end{array}$ & $\begin{array}{c}\mathrm{n}: 64 \\
(61.0 \%)\end{array}$ & $\begin{array}{c}n: 17 \\
(16.2 \%)\end{array}$ & 105 \\
\hline $\mathrm{BMI}>50$ & $\begin{array}{c}\text { n: } 8 \\
(15.4 \%)\end{array}$ & $\begin{array}{c}\text { n: } 26 \\
(50.0 \%)\end{array}$ & $\begin{array}{c}n: 18 \\
(34.6 \%)\end{array}$ & 52 \\
\hline All BMls & $\begin{array}{c}\mathrm{n}: 48 \\
(22.6 \%)\end{array}$ & $\begin{array}{c}\text { n: } 123 \\
\text { (57.5\%) }\end{array}$ & $\begin{array}{c}\mathrm{n}: 41 \\
(19.9 \%)\end{array}$ & 212 \\
\hline
\end{tabular}

BMI: body mass index; n: number

\section{WOMEN (n:127)}

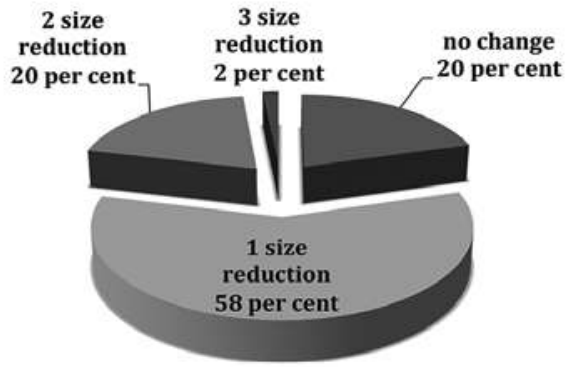

MEN (n:85)

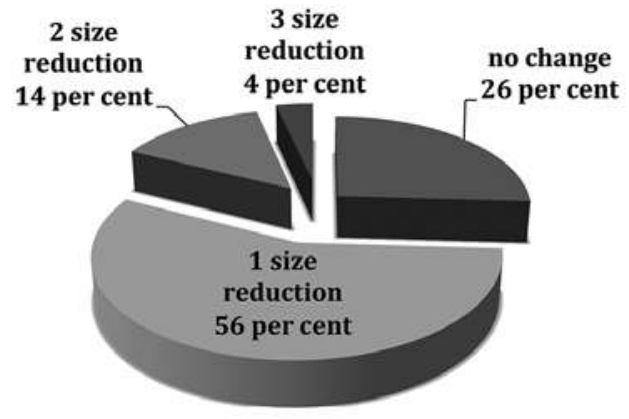

Figure 2. Distributions of shoe size changes in women and men 304

ciation was statistically significant for super obesity. Patients with $\mathrm{BMI}>50$ had a significantly high shoe size decrease compared to patients with $B M l<40(p=0.008)$. The shoe size change categories according to the BMI groups are summarized in Table 2 . In contrast to patients with $\mathrm{BMI}>50$, who had a $34.6 \%$ rate of at least 2 size changes, patients with $B M I<40$ had a rate of $10.9 \%$ ( $p=0.009)$. EWL $\%$ at one year, regardless of increase or decrease, was not associated with decrease in shoe size $(p=0.46)$.

\section{DISCUSSION}

Currently, obesity is a pandemic; morbid obesity, which is also endemic, is the second most common preventable cause of death, only following smoking $(13,14)$. It is also known that in both men and women, there has been a constant increase in average shoe size, especially during the last five decades; according to the College of Podiatry of the United Kingdom, this phenomenon is thought to be related to the ongoing increase in the obesity pandemic (15).

If becoming obese has an association with an increase in shoe size, hypothetically, the reverse could also be true; also, it is reasonable to assume that weight loss surgery may result in a smaller shoe size. We, as bariatric surgeons, actually observed a relevant trend, which is why we undertook the present study. Our results actually confirm this hypothesis and provide scientific documentation that weight loss surgery achieves a significant decrease in shoe size. Furthermore, this is especially true in super obese patients, further suggesting a direct relationship between obesity and shoe size. One year after SG, $80 \%$ of women and $75 \%$ of men experienced at least one size decrease compared to their preoperative shoe sizes, which was found to be highly significant $(p<0.001$, Table 1 , Figure 1,2$)$. It is also noteworthy that almost one fifth of the patients had a decrease of at least two sizes. The extents of decrease in shoe size were similar in both sexes; this is also true for patients older than 40 years of age compared to younger patients. Interestingly, the extent of EWL \% one year after SG also had no effect on the decreasing trend; however, this is not surprising. It is known that the EWL $\%$ is higher in patients with lower BMI, as these patients have less weight to lose (11). It is also shown in the present study that in this group of patients (BMI $<40$ ), the decrease in shoe size is significantly less than in patients with $\mathrm{BMI}>50$.

According to our results, postoperative shoe size decrease is mainly dependent on the patient's weight before surgery rather than how much of the patient's excess weight was lost. We are aware of the limitations of verbal reports of shoe size change compared to direct foot size measurements; however, this would be especially true if we wished to show that the patients' feet decreased in size in accordance with the decrease in shoe size. As our main aim was simply to assess the probability of changes in shoe size, more detailed and complicated measurements of three-dimensional foot size are irrelevant to the present study. Furthermore, as no half-size or arbitrary decreases were taken into account, our reduction rates actually reflected a minimum rate, which is still highly significant when compared to preoperative shoe size.

The mechanics, physics, and chemistry behind the decrease in foot or shoe size are beyond the scope of this article. Decrease 
in foot adipose tissue, decreased lymphedema, increased venous drainage, and correction of the arch height may all have effects; however, the fact remains that almost $80 \%$ of people who undergo SG will buy shoes at least one size smaller one year after SG. Super obesity is associated with significantly higher rates of shoe size decrease compared to lower BMls, and almost $35 \%$ of patients with a $\mathrm{BMI}>50$ will experience at least two size decreases.

Ethics Committee Approval: Authors declared that the research was conducted according to the principles of the World Medical Association Declaration of Helsinki "Ethical Principles for Medical Research Involving Human Subjects" (amended in October 2013).

Informed Consent: Written informed consent was obtained from patients who participated in this study.

Peer-review: Externally peer-reviewed.

Author Contributions: Concept - M.A.Y., O.Ş., A.G.T.; Design - M.A.Y., O.Ş., A.G.T.; Supervision - M.A.Y., O.Ş., A.G.T.; Resource - O.Ş., M.A.Y., A.G.T.; Materials - O.Ş., M.A.Y., A.G.T.; Data Collection and/or Processing - O.Ş., M.A.Y., A.G.T.; Analysis and/or Interpretation - O.Ş., M.A.Y., A.G.T.; Literature Search - O.Ş., M.A.Y., A.G.T.; Writing Manuscript - O.Ş., M.A.Y., A.G.T.; Critical Reviews - O.Ş., M.A.Y., A.G.T.

Conflict of Interest: No conflict of interest was declared by the authors.

Financial Disclosure: The authors declared that this study has received no financial support.

\section{REFERENCES}

1. Flum Dr, Dellinger EP. Impact of gastric bypass operation on survival: a population-based analysis. J Am Coll Surg 2004; 199: 543551. [CrossRef]

2. Sjöström L. Swedish Obese Subjects: a review of results from a prospective controlled intervention trial. In: Bray GA, Bouchard C, eds. Handbook of Obesity. Third edn. New York, NY: Informa Health Care; 2008: 503-515. [CrossRef]

3. Adams TD, Gress RE, Smith SC, Halverson RC, Simper SC, Rosamond WD et al. Long-term mortality after gastric bypass surgery. N Engl J Med 2007; 357: 753- 761. [CrossRef]
4. Adams TD, Mehta TS, Davidson LE, Hunt SC. All-cause and causespecific mortality associated with bariatric surgery: A review. Curr Atheroscler Rep 2015; 17: 74. [CrossRef]

5. Arterburn DE, Olsen MK, Smith VA, Livingson EH, Van Scoyoc L, Yancy Jr WS, et al. Association between bariatric surgery and long-term survival. JAMA 2015; 313: 62-70. [CrossRef]

6. Schauer DP, Arterburn DE, Livingstone EH, Coleman KJ, Sidney $\mathrm{S}$, Fisher $\mathrm{D}$, et al. Impact of bariatric surgery on life expectancy in severely obese patients with diabetes: a decision analysis. Ann Surg 2015; 262: 914-919. [CrossRef]

7. Johnson EE, Simpson AN, Harvey JB, Locket MA, Byme KT, Simpson KN. Trends in bariatric surgery, 2002-2012: do changes parallel the obesity trend? Surg Obes Relat Dis 2016; 12: 398-404. [CrossRef]

8. Gagner M, Deitel M, EricksonAL, Crosby RD. Survey of laparoscopic sleeve gastrectomy at the fourth international consensus summit on sleeve gastrectomy. Obes Surg 2013; 23: 2013-2017. [CrossRef]

9. Buwen JP, Kammerer MR, Beekley AC, Tichansky DS. Laparoscopic sleeve gastrectomy: The rightful gold standard weight loss procedure. Surg Obes Relat Dis 2015; 11: 1383-1385. [CrossRef]

10. Khorgami Z, Andalib A, Corcelles R, Aminian A, Brethauer S, Schauer $P$. Recent national trends in the surgical treatment of obesity: Sleeve gastrectomy dominates. Surg Obes Relat Dis 2015; 11: S6-S8. [CrossRef]

11. Maiz C, Alvarado J, Quezada N, Salinas J, Funke R, Boza C. Bariatric surgery in 1119 patients with preoperative body mass index $<35$ $(\mathrm{kg} / \mathrm{m} 2)$ : results at one year. Surg Obes Relat Dis 2015; 11: 11271133. [CrossRef]

12. Obeidat F, Shanti H, Mismar A, Albsoul N, Al-Qudah M. The magnitude of antral resection in laparoscopic sleeve gastrectomy and its relationship to excess weight loss. Obes Surg 2015; 25: 19281932.[CrossRef]

13. Ng M, Fleming T, Robinson $M$, Thomson B, Graetz N, Margono $C$, et al. Global, regional, and national prevalence of overweight and obesity in children and adults during 1980-2013: a systematic analysis for the global burden of disease study 2013. Lancet 2014; 384: 766-781. [CrossRef]

14. Jia $\mathrm{H}$, Lubetkin EL. Trends in quality-adjusted life-years lost contributed by smoking and obesity. Am J Prev Med 2010; 38: 138144. [CrossRef]

15. Society of chiropodists and podiastrists. A study on 2000 British adults. Published 2015 June: http://www.scpod.org/contact-us/ press/press. 